\title{
Employee Turnover In The Small Business: Practical Insights From Urban Child Care Centers
}

\author{
M. Ruhul Amin (E-mail:mamin@bloomu.edu), Bloomsburg University \\ Ahmed Zaman (E-mail:a_zaman_99@yahoo.com), Borough of Manhattan Community College \\ Nafeez A. Amin (E-mail:nafeezamin@hotmail.com)
}

\begin{abstract}
This paper investigates the claims of alarming turnover rates in the childcare work force (as claimed by the Center for the Childcare workforce) in the context of organizational literature. Data collected from 70 childcare centers of New York City partially support the traditional claim that behavioral variables (such as job satisfaction and commitment) explain variations in turnover rate. Additionally, it claims that negative work outcomes (or work itself could be cause of voluntary turnover) in this instance, the behavior problem, discipline problem, funding uncertainty and the like may be included in any deterministic model of employee turnover. Finally, this study did not find overwhelming evidence supporting the alarming rate of turnover in the childcare centers.
\end{abstract}

\section{Introduction}

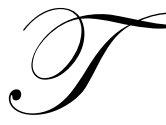

he organizational literature dealing with turnover generally defines it as voluntary separation of individual from an organization (Price and Mueller, 1981). Turnover is a dysfunctional aspect of organization (Dalton et al, 1982) and it is generally agreed upon to be an important management issue - that, it is a costly ( McConnell, 1999) phenomenon, generally disruptive for the organization (it is often beneficial to both individuals as well as the organization -see Dalton et al, 1982), it affects employee performance (Anderson and Buchholz, 2001), and consequently, it should be carefully managed so that the rate is reduced, and keep adverse impact under control.

Based on a longitudinal study, the Center for the Child Care Workforce in a recent release (Whitebook, Sakai, Lombardi, \& Culbreth, 2001) stated that "Child care centers, and the child care industry as a whole, are losing well -educated teaching staff and administrators at an alarming rate, and hiring replacements teachers with less training and education." It also stated that high employee turnover "negatively affected their ability to do their jobs, and for some, contributed to their decision to leave." In fact, high turnover rate is argued to be a characteristic of the childcare industry (Brown, 2001). While the industry is expanding by leaps and bounds, it is imperative that scholars of business come forward to assist the emerging managerial/entrepreneurial class with empirically grounded theories.

The U.S. Census Bureau predicts that one-half of all children born in the first decade of the twenty-first century will live with a single parent at some point by the time they turn 18 years of age. In 1998, 34.7 million families had children under the age of 18 (Rogensburger, 2001). The increasing participation of mothers in the paid workforce enhanced the propensity of corporate and governmental recognition and support for child and infant care. As such, the business of childcare centers has been continuously growing. Since 1963, the percentage of women in the workforce shifted from $34 \%$ to $45 \%$. By 2005, women are estimated to make up 57\% of all new entrants and they soon will constitute almost $50 \%$ of the workforce (Whigham-Desir, 1993). In addition, the percentage of mothers with children under six years of age doubled between 1970 and 2000 from 32 percent to 65 percent (Smith, 2000). Consequently, the share of children under age five enrolled in center based care increased between 1977 and 1993, from 13 percent to 30 percent (USHR,1996). Stoney and Greenberg (1996) suggest that an estimated $\$ 40$ 
billion is being spent annually through the parental, governmental, the charitable and the corporate contributions combined. As the market expands, more and more enterprises and corporations enter the market.

High turnover rate in the childcare workforce confounds adversely the business characteristics of this sector with massive labor intensity, no economies of scale, weak brand distinction, chronically low profit margin, heavy regulatory oversight, and the existence of a large body of non legal facilities competing. Such a situation creates a volatile market and sustainability conditions for the childcare centers. No other sector of the workforce with the probable exception of nursing, where turnover is argued to be an issue of domestic as well as international concern in the hospitals (Hom and Griffeth, 1991; Hom and Kinicki, 2001; Fang, 2001) and the challenge of turnover is acutely felt and dealt with on a recurrent basis. It is in this context that this paper is written - to examine the empirically grounded problem of turnover in the childcare workforce in the context of the existing organizational literature. It is expected that findings will lead to useful managerial imperatives for childcare centers.

As early as 1982 Bluedorn reported that over 1,500 studies of turnover have been conducted in the past century. Numerous papers on the topic since 1982 appeared both on the cause as well as the effect of turnover (for instance, Borjas, 1984;Kemery et al, 1985; Jackson Schuler, 1985; Hollenbeck and Williams, 1986; DeCotiis and Summers, 1987; Harrison et.al, 1988; Hackett and Alvares, 1990; Ingram and lee, 1990; Sager, 1990; Hom and Griffeth, 1991; Fang and Baba,1993; Arthur,1994; DeConick and Bachmann, 1994; Sin,1994; Crandall and Perrewe, 1995; Aquino et al.,1997 ; Lee et al., 1999; Iverson and Pullman, 2000;Dess and Shaw, 2001; Steel, 2002; Droege and Hoobler, 2003) in various occupational categories. Part of the explanation as to why such an overwhelming interest exist on the topic, was probably due to the fact that both causes and their relative impacts of turnover vary across occupations (Atchison and Lefferts, 1972; Krackhardt and Porter, 1981; Arthur, 1994; DeConinck and Bachmann,1994; Hom and Kinicki, 2001; Fang,2001), industries and services ( Bluedorn, 1982; Gender (Borjas, 1984; Theodossiou, 2002), age ( Healy et al., 1995; Iverson and Pullman, 2000), the levels of management (Furtado and Karan, 1990; Harrison et al., 1988); and the labor market conditions (Anderson and Buchholz, 2001, Longennecker and Scazzero, 2003). In fact, the literature gained from the contributions of economists, especially the labor economists, social, behavioral, and psychological perspectives over a century. Persistent intellectual endeavors, and case studies led to methodological improvements (Bluedorn, 1982; Dalton et. al, 1982; Hom and Griffeth, 1991; Morita et al, 1993; Quarles, 1994; Williams and Livingstone, 1994; Lee et al, 1999; Steel, 2002) as well as determinism in theory building in this area. However, the child care sector where the problem seems to be more acute still remains neglected, and under studied ( Zaman \& Amin, 2003). From data collected from 70 private childcare centers in New York City authors seek to verify the claims of acuteness of the turnover as an HR issue and review solutions within the existing theoretical framework.

\section{Hypotheses}

H1: Higher the level of job satisfaction, lower is the turnover rate in the childcare centers

H2: Higher the level of commitment, lower is the turnover rate in the childcare centers

H3: Higher the level of job enrichment, lower is the turnover rate in the childcare centers

H4: Higher the level of motivation, lower is the turnover rate in the childcare centers

H5: Higher the compensation, lower is the turnover rate in the childcare centers

H6: Turnover rate tend to be higher in centers with high incidence of clientele problems (i.e. negative outcomes) irrespective of compensation, job satisfaction and commitment.

H7: Higher the behavior profile, lower is the incidence of negative outcomes and consequently lower is the turnover rate.

Job satisfaction and organizational commitment are center pieces of turnover theory (Steel, 2002). Job satisfaction was found to be inversely related to turnover (Vroom, 1964; Tett and Meyer, 1993; Hulin 1966; Kemery et al., 1985; Gerhart, 1990; Quarles, 1994; Ameen et. al, 1995;Lee et. al, 1999; Hom and Kinicki, 2001). Commitment is also found to be inversely related to turnover ( Steers and Mowday, 1981; Bluedorn,1982;Kemery et al, 1985; Tett and Meyer, 1993; Arthur, 1994;Quarles, 1994; DeConinck and Bachmann, 1994;Ameen et al, 1995; Crandall and Perrewe, 1995; Somers and Birnbaum, 2000; Steel, 2002). Herzberg (2003) argued job it self as a source of satisfaction, and claimed job enrichment as employee motivating device with implication for decreased 
turnover rates and increased performance (also, Williams and Livinstone, 1994; Amin et al, 2003). Vroom (1964) before Herzberg saw positive impact of higher motivation to reduced turnover rates. Labor Economists (i.e. Borjas, 1984; Leonard and Jacobson, 1990; Anderson and Rogene, 2001), Center for Childcare Workforce (2001), and many other scholars (such as, McConnell, 1999; Abbasi and Hollman, 2000) indicate tight labor market condition and or low compensation package contribute to higher turnover rates. The above studies form the bases for first five hypotheses. In addition, relying on job itself as a source of satisfaction (James, 2002) and of motivation (Herzberg, 2003) $\mathrm{H}_{6}$, and based on the recent findings about the relationship between composite behavior profile and the negative outcomes in the child care center (Amin, Zaman, \& Amin, 2003), $\mathrm{H}_{7}$ above have been proposed.

\section{Methods And Measurement}

A mail questionnaire instrument was developed to conduct the study. The instrument elicited factual information from the Director/Owner of the centers. The questionnaire consists of five distinct sections: a. General Profile of the Childcare centers, b. Internal/External aspects of operation, c. HR profile and strategies, d. Goals and Missions, and e. Business Challenges. A draft questionnaire was sent to the Bureau of Day Care of the New York City Department of Health for possible modification. It was then used for a pilot survey among 25 childcare centers. Based on this pilot survey, the questionnaire was modified and finalized for the final survey. In addition to questions pertaining to general profile (i.e., age of the center, number of employees, owner/manager's educational level, ethnic composition of employees and children), specific questions on recruitment strategies, fees, profitability, and other financial questions such as total revenues in the previous year were asked. The directors were asked to rate (from "Highly Agree" = 1, to "Highly Disagree" = 5) various statements about internal/external environment and the operation of the center, bureaucratic profile, mission and goals, nature of personnel practices, managerial attributes and aspects of business operations. In addition, directors were asked questions regarding the challenges that the center faces (behavior and discipline issues of the children, external competition, employee turnover, etc).

Privately financed centers make-up about half of all preschool organizations (excluding the family day care); and another one-fourth receive subsidies that comprise between $1 \%$ and $80 \%$ of their operating budget. Over one-half of all government support for childcare flows in the form of tax credits or targeted vouchers (Fuller et. al. 1993).

The sample for this study consisted of 70 privately owned childcare centers attended primarily by minority children from the five boroughs of New York City. This was a sampling based on the ethnic concentration of city neighborhoods where more than $60 \%$ of the children belonged to ethnic minority groups (e.g., African-American, Latino-American, Asian-American and others). Approximately 200 privately owned childcare center directors were contacted from a list from the New York City Department of Health. One hundred and eighteen of them agreed to participate. Accordingly, a letter of explanation, assurances of confidentiality, a questionnaire instrument, and a stamped addressed envelope were mailed with anticipated completion by the center directors. A total of 91 $(77.11 \%)$ completed questionnaires were returned. Of these, 21 were considered unusable because they were incomplete. Thus the data of this study comes from $70(n=70)$ questionnaires that represent $76.92 \%$ of the questionnaires received.

Negative outcome (NOUT) as a composite variable was conceptualized in terms of managerial problems and issues. These outcomes are dichotomized categorical variables (with 0,1 values) in the instrument. Job enrichment as proposed by Herzberg (2003) included empowerment and the individual's ability to design his/her own jobs. Furthermore, organizational behavior profile included items of perceived motivation, morale, job satisfaction, commitment, and employee dedication. This scale (Behavpro) produced a high alpha reliability coefficient of a=.83. Finally, negative outcome (Nout) was measured by adding six dichotomous items (i.e., children's behavior problems, discipline problems, and the like). This composite scale produced an alpha reliability of $a=.70$.

\section{Findings}

Data shows that 31 percent of the centers agreed that there is a high turnover rate among childcare workforce, and 26 percent of the centers agreed that high turnover rate is a managerial problem for them. Table-1 below 
shows zero order correlation coefficients for the selected variables with perceived high turnover rates. It seems that the high turnover rate is inversely related to centers encouraging employee feed back in major decisions ( $\mathrm{r}=.438)$. A corollary variable, 'employees demonstrate dedication in their assigned duties' also shows significant inverse relationship ( $\mathrm{r}=-.409)$. Turnover is also inversely related to centers having established procedures for handling employee grievances and conflicts ( $\mathrm{r}=-.462)$. Turnover seems to be higher for centers with perceived higher future uncertainty $(\mathrm{r}=.53)$. Existence of significant behavior problems of the child $(\mathrm{r}=.327)$, and discipline problem of the child $(r=.337)$ are positively correlated with high turnover rates. Centers that are committed to workplace diversity and affirmative action seem to experience lower turnover rates $(\mathrm{r}=.-442)$. It is interesting to note that the findings regarding no job availability (NoJob) verify the condition of the labor market having an important bearing on the high turnover rate. If the childcare staffing reflects that a substantial portion of it's workforce is there due to non availability of jobs elsewhere, it should significantly and positively contribute to high turnover rates, and does $(\mathrm{r}=.361)$. Negative outcomes comprised of a number of items, including clientele problems, and managerial challenges also shows a significant positive association with high turnover rates.

The universally accepted (in the literature) independent variables having inverse associations with turnover as reflected in the first few hypotheses, such as, job satisfaction, commitment and motivation found support only in the direction (-) of the association. None of the coefficients are significant at an acceptable level. Perhaps the small sample size partially explains the small magnitude of and insignificant association with high turnover rate.

For hypothesis $\mathrm{H}_{5}$, zero order correlation between high turnover rate and low salary indicates $(\mathrm{r}=-.21)$ indicates a negative association but the coefficient is not significant. One way ANOVA between high turnover as a problem and low salary scales did not produce significant $\mathrm{F}$ statistics. Therefore, while the claim of low salary as a cause of turnover was generally supported, it did not turnout to be a significant variable explaining high turnover.

Table -2 shows findings of several regression equations pertaining to the hypotheses stated earlier. A sub sample of centers with high turnover rates (where high turnover is a managerial issue) was selected for the regression equations. Equation-1 is based on traditional explanations of turnover rates. Employee commitment, motivation, job satisfaction, and morale were independent variables explaining the dependent variable, i.e. the high turnover rates. All the independent variables were entered together in the equation so that each coefficient shows the magnitude of association while controlling the impact of others. The multiple $\mathrm{R}=.493$ shows a substantial multiple association with a raw $R^{2}=.243$. However, the $F$ statistics for this equation was also not significant. None of the $B$ coefficients is significant although coefficients for motivation $(B=-.372)$, job satisfaction $(B=-.273$, enrichment $(B=-$ .074) and commitment ( $\mathrm{B}=-04)$ support the inverse association as proposed in the hypotheses $\mathrm{H}_{1}, \mathrm{H}_{2}, \mathrm{H}_{3}$ and $\mathrm{H}_{4}$.

Equation 1 shows findings for Hypothesis 1-4. The standardized B coefficients again support the (hypothesized) zero order inverse relationships when the impact of all the variables are controlled for in one equation. The independent variables together explain about $25\left(\mathrm{R}^{2}=.247\right)$ percent of the variance in the high turnover rate. However, none of the coefficients as well as F statistics is significant.

Equation-2 addresses hypothesis $\mathrm{H}_{6}$. Negative outcomes such as discipline problem, behavior problems of the children, and like, have strong and significant positive association $(B=.328)$ with high turnover rates. Zero order associations in table -1 also did the same. When job satisfaction, motivation, and commitment were entered together, the positive association was not affected a great deal $(B=.308)$, although $F$ value declined sharply. This hypothesis therefore was verified by empirical evidence.

Zero-order analysis established that Behavior profile is inversely as well significantly associated with negative outcomes ( $\mathrm{r}=.498)$. Equation-3 further addresses hypothesis $\mathrm{H}_{7}$. The $\mathrm{B}$ coefficient (.337) and $\mathrm{F}$ statistics $(\mathrm{F}=4.57)$ are significant while the effects of low salary and behavior profile were controlled by the equation. This finding demonstrates support for hypothesis $\mathrm{H}_{7}$. 
Table 1

Zero-Order Correlation Coefficients

\begin{tabular}{|c|c|c|c|c|c|c|c|c|c|c|c|c|c|c|c|c|}
\hline & Turn & $\begin{array}{l}\text { Job } \\
\text { Sat }\end{array}$ & Morale & Motiv & Commit & $\begin{array}{l}\text { Feed- } \\
\text { back }\end{array}$ & $\begin{array}{l}\text { DemDe } \\
\text { d }\end{array}$ & Grieve & Uncert & $\begin{array}{l}\text { Behav. } \\
\text { Prob. }\end{array}$ & $\begin{array}{l}\text { Dici } \\
\text { Prob }\end{array}$ & Enrich & Profit & Nout & No Job & Affirm \\
\hline Turnover & 1.00 & -.005 & -163 & -072 & -146 & $-412 * *$ & $-409 * *$ & $-462 * *$ & .018 &. $.327 *$ &. $.337 *$ & $\begin{array}{l}-103 \\
\end{array}$ & -228 &. $.327 *$ &. $.361^{*}$ & -.442 *** \\
\hline Job Sat & -005 & $\mathrm{X}$ & $.465^{* * *}$ &. $.566 * *$ & $.625 * *$ & $* .039$ & .174 & .163 & -324 & $\begin{array}{l}-.076 \\
\end{array}$ & -.089 & $.499^{* * *}$ & .057 & $\begin{array}{l}-.120 \\
\end{array}$ & -065 & -199 \\
\hline Morale & -.163 & $.465^{* * *}$ & $\mathrm{X}$ & $.661^{* * *}$ & $.646^{* * *}$ & -.123 & $.424 * *$ & .091 & -184 & -223 & $.424 * *$ & .228 & .006 & $-307 *$ & $-320^{*}$ & -.197 \\
\hline Motiv & -072 & $.566^{*}$ & $.665^{*}$ & $\mathrm{X}$ &. $.554 * *$ & -026 & $.286^{*}$ & .130 & $-280^{*}$ & -148 & .286 & $.401^{* *}$ & .082 & $-272 *$ & -155 & $-243^{*}$ \\
\hline Commit & $\begin{array}{l}-.146 \\
\end{array}$ & $.625^{* * *}$ & $.646^{* * *}$ &. $.544 * *$ & $\mathrm{X}$ & .174 & $.366^{*}$ & .011 & -157 & -115 & .366 & .402 & .016 & $\begin{array}{l}-.222 \\
\end{array}$ & -166 & -056 \\
\hline Feedback & -.412 & .039 & .123 & .-026 & .174 & $\mathrm{X}$ &. $.556^{* * *}$ & $328^{*}$ & -086 & $-.457 *$ & -298 & .056 & .068 & $-383^{*}$ & $.301 *$ & $-.349^{*}$ \\
\hline DemDed & $-.409 * *$ & .174 & $.424 * *$ & $.286^{*}$ &. $.366^{*}$ &. $.556^{* * *}$ & $\mathrm{X}$ & $.270^{*}$ & -124 & $-403 * *$ & -.086 & .058 & .088 & $-418 * *$ &.$- .353^{*}$ & -.205 \\
\hline Grieve & $-.462 * *$ & .163 & .091 & .130 & .011 &. $.328 *$ & ..276* & $\mathrm{X}$ & $\begin{array}{l}-.214 \\
\end{array}$ & $-.260 *$ & $-.269 *$ &. $.297 *$ &. $.328 *$ & -206 & $\begin{array}{l}-.148 \\
\end{array}$ & $.761^{* *}$ \\
\hline Uncert & .018 & $-.324 *$ & -184 & -.280 & .157 & -086 & -124 & -214 & $\mathrm{X}$ & $.238^{*}$ & -324 &. $.311^{* * *}$ & -.261 & -148 & -.041 & .127 \\
\hline Behav. Prob. &. $.327 *$ & $\begin{array}{l}-.076 \\
\end{array}$ & -223 & $\begin{array}{l}-148 \\
\end{array}$ & -115 & $-.457 * *$ & $-.403 * *$ & $-260^{*}$ & $.238^{*}$ & $\mathrm{X}$ & $.652^{* * *}$ & $\begin{array}{l}-.039 \\
\end{array}$ & $\begin{array}{l}-.062 \\
\end{array}$ & -041 & $.291 *$ & .129 \\
\hline DiciProb & $.337 *$ & $\begin{array}{l}-.089 \\
\end{array}$ & $-241 *$ & -20 & $-.256^{*}$ & $-.298 *$ & $\begin{array}{l}-.086 \\
\end{array}$ & $-.269 *$ & $-.324 *$ & $.642 * *$ & $\mathrm{X}$ & -.015 & -086 & $.291^{*}$ & .154 & .182 \\
\hline Enrich & -103 & $.499 * *$ & .228 & $.401 * *$ & $.402 * *$ & .056 & .058 & $.297^{*}$ & $.311 * *$ & -.039 & -.015 & $\mathrm{X}$ &. .232 & .154 & 0.17 & $.440 * *$ \\
\hline Profit & -.228 & .057 & .006 & -082 & .016 & .068 & .088 &. $.328 *$ & $-.261 *$ & -.061 & .086 & .232 & $\mathrm{X}$ & -165 & $.263^{*}$ & $.362 *$ \\
\hline Nout & $.327^{*}$ & -120 & $-307 *$ & $.272 *$ & -.222 & $-383^{*}$ & $-.418^{* * *}$ & -.206 & $.304 *$ & $.822 * *$ & $.877 * *$ & .154 & -.165 & $\mathrm{X}$ & -.223 & -076 \\
\hline No Job & $.361^{*}$ & -.065 & $-.320 *$ & -.155 & -166 & $301 *$ &.$- .353 *$ & -.148 & -.041 & $.291 *$ & .154 & -.17 &. $.263 *$ & -.223 & $\mathrm{X}$ & -.226 \\
\hline Affirm & $-.442 *$ & $\begin{array}{l}-199 \\
\end{array}$ & -197 & $-243^{*}$ & .056 & $-349 *$ & -.205 & $.261^{*}$ & -.127 & .129 & .182 & $.440^{* * *}$ &. $.362 *$ & $\begin{array}{l}-.076 \\
\end{array}$ & -226 & $\mathrm{X}$ \\
\hline
\end{tabular}

* $\quad$ significant at 05 level

Turn/Turnover=High turnover rate

Nout=Negative outcome

Jobsat=Job satisfaction

NoJob $=$ No job availability

Motiv=Employee motivation

Affirm=Committed to affirmative action

Commit=Employee Commitment
Feedback=Employees are encouraged to provide feedback in decision making

DemDed=Employee demonstrates dedication

Grieve=Established grievance procedure

Uncert=Funding uncertainty

BehavProb=Behavior problem

DeciProb=Discipline Problem
Enrich=Job enrichment 
Table-2

Regression Coefficients

\begin{tabular}{|c|c|c|c|c|}
\hline & Dependent Var & B & $\mathbf{R}^{2}$ & $\mathbf{F}$ \\
\hline \multicolumn{5}{|l|}{ Equation-1 } \\
\hline Motivation & High Turnover & -.395 & .247 & 1.31 \\
\hline Jobsat & & -.294 & & \\
\hline Commitment & & -.060 & & \\
\hline Enrichment & & -.074 & & \\
\hline Morale & & -.273 & & \\
\hline \multicolumn{5}{|l|}{ Equation-2 } \\
\hline Noutcomes (Stepwise) & & $.328 * *$ & .108 & $8.078 * *$ \\
\hline Noutcomes (Enter) & & $.308^{*}$ & .132 & 2.42 \\
\hline Jobsat & & -.155 & & \\
\hline Motivation & & -.017 & & \\
\hline Commitment & & -.196 & & \\
\hline \multicolumn{5}{|l|}{ Equation-3 } \\
\hline Noutcomes & & $.337 * *$ & .122 & $4.57 *$ \\
\hline Behavpro & & -.119 & & \\
\hline Low salary & & -.002 & & \\
\hline
\end{tabular}

* Significant at .05 level

** Significant at .00 level

\section{Conclusion}

This study tested 7 hypotheses derived from the current body of organizational literature on turnover rate. This study used a sample of 70 privately owned childcare centers in New York City. All of the 7 hypotheses are either partially or fully supported by the empirical evidence. It was noteworthy that traditional causes for high voluntary turnover, such as low job satisfaction, low commitment, and low motivation did not show significant inverse association as was expected. However, many all of the insignificant coefficients (rs and Bs) would become significant simply by enlarging sample size. Low compensation also did not emerge a significant cause of high turnover rate in this study. Negative outcomes in the center such as, discipline problem, behavior problem, funding uncertainty, and the like seem to be important variables explaining high turnover rates in the childcare industry. Finally, the findings although supported the notion of higher turnover rate as a problem in the childcare workforce, but authors did not see a sign of alarm in this sample (only 31 percent believe that there is high turnover in the workforce, and only 26 percent agreed that it is a managerial problem for them) as claimed by the Center for the Childcare Workforce (Whitebook, Sakai, Lombardi, \& Culbreth, 2001) based on their longitudinal work.

Thus, it seems that this study attempts to reaffirm that, beside the traditional dependent variables such as job satisfaction, commitment, motivation, morale and their usual correlates such as enrichment, empowerment, other sector/occupation specific variables may need to be included for turnover studies. From this study, it is evident that the work itself (James, 2002), the negative outcomes from the work, and the perceived funding uncertainty (i. e. job security) should in fact be seriously looked at in developing any deterministic model of employee turnover.

\section{References}

1. Abbasi, S.M. and Hollman, K.W., (2000), "Turnover: The Real Bottom Line", Public Personnel Management, Vol. 29, No. 3, pp. 333-342.

2. Allen, D. et. al, (2003), "The Role of Perceived Organizational Support and Supportive Human Resource Practices in the Turnover Process", Journal of Management, Vol. 29 Issue 1, p. 99, 20.

3. Ameen, E.C. et. al, (2001), “An Empirical Investigation of the Antecedents and Consequences of Job Insecurity on the Turnover Intentions of Academic Accountants", Issues to Accounting Education, Vol. 10(1), pp. 65-82. 
4. Amin, M.R., Zaman, A, \& Amin, N. A. (2003), "Organizational Profile, HR Practices and the Perceived Quality and Performance of Small Businesses: Empirical Highlights from the Urban Child Care Centers”, International Business and Economic Research Journal, Vol. 2 (6) pp. 95-105.

5. Anderson, E.E. and Buckholz R.A., (2001), "Economic Instability and Occupational Injuries: The Impact of Overtime Hours and Turnover Rates”, pp. 33-49.

6. Aquino, et. al. (1997), "Integrating Justice Constructs into the Turnover Process: A Test of a Referent Cognitions Model”, Academy of Management Journal, Vol. 40(5), pp. 1208-27.

7. Arthur, J.B., (1994), "Effects of Human Resource Systems on Manufacturing Performance and Turnover", Academy of Management Journal, Vol. 37(3), pp. 670-687.

8. Atchison, T.J. and Lefferts, E.A., (1972), “The Prediction of Turnover using Herzberg's Job Satisfaction Technique", Personnel Psychology, Vol. 25, pp. 53-64.

9. Bluedorn, A.C. and Abeldon, M.A., (1981), "Employee performance and withdrawal from work", Unpublished manuscript, College of Business Administration, Pennsylvania State University, University Park.

10. Borjas, G.J., (1984), "Race, Turnover, and Male Earnings”, Industrial Relations, Vol. 23(1), pp. 73-89.

11. Brown, R., (2001), "How We Built a Strong Company in a Weak Industry", Harvard Business Review, February pp. 51-57.

12. Crandall, R. and Perrewe, P.L., (1995), Occupational Stress: A Handbook, Washington, D.C: Taylor \& Francis.

13. Dalton, 2`D.R. et. al., (1982), “Turnover Overstated: The Functional Taxonomy”, Academy of Management, Vol. 7(1), pp. 117-123.

14. Dess, G.G. and Shaw, J.D., (2001), "Voluntary Turnover, Social Capital, and Organizational Performance", Academy of Management Review, Vol. 26(3), pp. 446-456.

15. DeCotiis, T.A., and Summers, T.P., (1987), "A Path Analysis of a Model of the Antecedents and Consequences of Organizational Commitment”, Human Relations, Vol. 40(7), pp. 445-470.

16. Droege, S.B. and Hoobler, J.M., (2003), "Employee Turnover and Tacit Knowledge Diffusion: A Network Perspective", Journal of Managerial Issues, Vol. 15(1), pp. 50-64.

17. DeConinck, J.B. and Bachmann, D.P., (1994), “Organizational Commitment and Turnover Intentions of Marketing Managers", Journal of Applied Business Research, Vol. 10(3), pp. 1-11.

18. Fang, Y. and Baba, V.V. (1993), "Stress and Turnover: A Comparative Study Among Nurses", International Journal of Comparative Sociology, Vol. 34(1-2), pp. 24-38.

19. Fang, Y., (2001), "Turnover propensity and its causes among Singapore nurses: an empirical study", The International Journal of Human Resource Management, pp.859-871.

20. Fuller, B. et. al., (1996), "How Do Mothers Choose Childcare: The Center Piece of Organizing Family Life for Dual - earner Couples", Journal of Family Issues, Vol. 18(4).

21. Furtado, E.P.H. and Karan, K., (1990), "Causes, Consequences, and Shareholder Wealth Effects of Management Turnover: A Review of the Empirical Evidence”, pp. 60-75.

22. Gerhart, B. (1990), "Voluntary turnover and alternative job opportunities", Journal of Applied Psychology, Vol. 75 pp. 467-476.

23. Hackett, R.D. and Alvares, K.M, (1990), "Job performance and Turnover: A review and meta-analysis", Applied Psychology: An International Review, Vol. 39(1), pp. 47-76.

24. Harrison, J.R. et. al., (1988), "The Changing of the Guard: Turnover and Structural Change in the TopManagement Positions", Administrative Science Quarterly, Vol 33, pp. 211-232.

25. Healy, M.C. et. al., (1995), “Age and Voluntary Turnover: A Quantitative Review”, Personnel Psychology, Vol. 48, pp. 335-345.

26. Hollenbeck and Williams, (1986), "Turnover functionality versus turnover frequency: A note on work attitudes and organizational effectiveness". Journal of Applied Psychology, 71: 606-611.

27. Hom, P.W., and Griffeth, R.W., (1991), "Structural equations modeling test of a turnover theory: Crosssectional and longitudinal analysis", Journal of Applied Psychology, 76: 350-366.

28. Hom, P.W. and Kinicki, A.J., (2001), "Toward a Greater Understanding of How Dissatisfaction Drives Employee Turnover", Academy of Management Journal, Vol. 44(5).

29. Hulin, C.L., (1966), "Job Satisfaction and turnover in a female clerical population", Journal of Applied Psychology, Vol. 50, pp. 280-285. 
30. Ingram, T.N. and Lee, K.S., (1990), "Sales Force Commitment and Turnover", Industrial Marketing Management, Vol. 19(2), pp. 149-154.

31. Iverson, R.D. and Pullman, J.A., (2000), "Determinants of Voluntary Turnover and Layoffs in an Environment of Repeated Downsizing Following a Merger: An Event History Analysis", Journal of Management, Vol. 26(5), pp. 977-1003.

32. James, William, M. (2002), "Best Practices for Today's Innovation Management", Research Technology Management, Vol. 45(1), pp. 57-60.

33. Jackson, S. and Schuler, R., (1989), "Organizational characteristics as predictors of personnel practices", Personnel Psychology, Vol. 42, 727-786.

34. Kemery, E.R. et. al., (1989), "The Employee Separation Process: Criterion-Related Issues Associated with Tenure and Turnover", Journal of Management, Vol. 15(3), pp. 417-424.

35. Krackhardt, and Porter, (1981). "Supervisory behavior and employee turnover: A field experiment", Academy of Management Journal, Vol. 24, pp. 249-259.

36. Lee, T. et. al., (1999), "The unfolding model of voluntary turnover: A replication and extension", Academy of Management Journal, 42, pp. 450-462.

37. Leonard, J.S. and Jacobson, Louis, (1990), "Earnings Inequality and Job Turnover", American Economic Review, Vol. 80(2).

38. Longnecker, C.O. and Scazzero, J.A., (2003), "The Turnover and Retention of its Managers in Rapidly Changing Organizations", Information Systems Management, Vol. 20(1).

39. McConnell, C.R., (1999), "Staff Turnover: Occasional Friend, Frequent Foe, and Continuing Frustration", Health Care Manager, Vol. 18(1), pp. 1-13. Aspen Publishing, Inc.

40. Morita, J.G. et. al., (1993), "The Regression-Analog to Survival Analysis: A Selected Application to Turnover Research", Academy of Management Journal, Vol. 36(6), pp. 1430-1464.

41. Mueller, F., Garduque, L., (1996), "Human Resources as Strategic Assets: An Evolutionary ResourceBased Theory", Journal of Management Studies, Vol. 33(6), pp. 757-85.

42. Price, James, (1999), "Introduction to the Special Issue on Employee Turnover", Human Resource Management Review, Vol. 9(4), pp. 387-395.

43. Quarles, Ross, (1994), “An Empirical Examination of a Model of the Turnover”, Journal of Applied Business Research, Vol. 10(1).

44. Rogensburger, Linda (2001), The American Family: Reflecting a Changing Nation, Gale Group: New York, p. 20

45. Sager, J.K., (1990), "How to Retain Salespeople”, Industrial Marketing Management, Vol.19(2), pp. 155166.

46. Sin, L., (1994), "The Antecedents and Consequences of Role Stress in a Salesforce Context: A Study in an Asian Culture", Singapore Management Review, 17(1): pp. 67-89.

47. Smith, K., (2000), "Who is Minding the Kids? Childcare Arrangements of Commerce", Bureau of Census Current Population Reports.

48. Somers, M. and Birnbaum, D., (2000), "Exploring the Relationship between Commitment Profiles and Work Attitudes, Employee Withdrawal, and Job Performance”, Public Personnel Management, Vol. 29(3), pp. 353-364.

49. Staw, B.M., (1980), "The Consequence of Turnover", Journal of Occupational Behavior, Vol. 1(4).

50. Steel, R.P., (2002), “Turnover Theory at the Empirical Interface: Problems of Fit and Function”, Academy of Management Review, Vol. 27(3), pp. 346-360.

51. Tett, R.P. and Meyer, J.P., (1993), "Job Satisfaction, Organizational commitment, Turnover intention, and Turnover: Path analyses based on Meta-analytical Findings", Personnel Psychology, Vol. 46(2).

52. Theodossiou, I., (2002), "Factors Affecting the Job or Joblessness Turnover and Gender", Labour: Review of Labour Economics \& Industrial Relations, Vol. 16(4).

53. U.S. House of Representatives (Committee on Ways and Means, 1996), Green Book, Washington, Government Printing Office.

54. Vroom, Victor, (1964), Work and Motivation, New York: John Wiley and Sons.

55. Whigham-Desir, Marjorie, (1993), "Business \& Child Care", Black Enterprise, Vol. 24(5).

56. Whitebook, M., Sakai, L., Lombardi, J. \& Culbreth, J. (2001). Then and now: Changes in child care Staffing, 1994-2000 - Center for the Child Care Workforce. Washington, DC 
57. Williams, C.R. and Livingstone, L.P. (1994), "Another Look at the Relationship Between Performance and Voluntary Turnover", Academy of Management Journal, Vol. 37(2), pp. 269-298.

58. Zaman, A., \& Amin, M. R. (2003), "Ethnic Composition of the Clientele and the Managerial Challenges of Private Urban Child Care Centers: Some Strategic Implications”, Education, Vol. 123 (4), pp. 798-814.

Notes 
Notes 